\title{
INFLUENCE OF CUT, PACKAGING AND STORAGE TEMPERATURE ON PHYSICOCHEMICAL ASPECTS OF MINIMALLY PROCESSED CARICA PAPAYA CV. 'FORMOSA'
}

\author{
INFLUENCIA DEL CORTE, ENVASADO Y TEMPERATURA DE \\ ALMACENAMIENTO SOBRE ASPECTOS FISICOQUÍMICOS EN CARICA \\ PAPAYA CV. 'FORMOSA' MÍNIMAMENTE PROCESSADA
}

\author{
Paula Cristina Carvalho Lima ${ }^{1}$ \\ Bianca Sarzi de Souza ${ }^{2}$ \\ Selina Fyfe ${ }^{3}$ \\ ${ }^{1}$ Plant Biology Departament, Viçosa Federal University, Viçosa, Minas Gerais, Brazil. \\ 2 IFSULDEMINAS - campus Muzambinho, Minas Gerais, Brazil. \\ ${ }^{3}$ School of Agriculture and Food Sciences, The University of Queensland, Australia. \\ ${ }^{1}$ paulinhahlima@yahoo.com.br
}

\begin{abstract}
This study aims to verify the influence of cut, package and storage temperature on the physicochemical aspects of minimally processed 'Formosa' papaya. Fruits were selected, washed and sanitized, then stored for $12 \mathrm{~h}$ at $10^{\circ} \mathrm{C}$. At $12{ }^{\circ} \mathrm{C}$, they were peeled and cut longitudinally in half, the seeds and tips were removed, then the fruit was cut into slices in the transverse direction (1.5-2-cm thick) or cut into 4 parts. Cut pieces were rinsed, drained and packed either into polyethylene terephthalate (PET) containers or on Styrofoam trays wrapped in polyvinyl chloride (PVC) film and stored at 4 or $8^{\circ} \mathrm{C}$. During storage, they were evaluated for soluble solids, titratable acidity, vitamin C, color (lightness, hue angle and chroma), texture, weight loss and appearance. Physicochemical
\end{abstract}

results showed the products maintained adequate quality for consumption and commercialization for up to nine days. The fruit stored at $4{ }^{\circ} \mathrm{C}$ maintained better texture and color, had lower weight loss and higher levels of vitamin $\mathrm{C}$ than those stored at $8^{\circ} \mathrm{C}$. The PET packaging minimized weight loss and the transverse direction cut type promoted less damage to the tissues, maintaining the quality and characteristics of the fresh fruit.

Keywords: 'Formosa' papaya, postharvest, storage, quality, texture.

\section{Resumen}

El objetivo de este trabajo fue verificar la influencia del corte, envasado y temperatura de 
almacenamiento sobre aspectos fisicoquímicos en papaya 'Formosa' mínimamente procesada. Los frutos fueron seleccionados, lavados, desinfectados, y luego almacenados durante 12 $\mathrm{h}$ a $10^{\circ} \mathrm{C}$. Después de esto, a $12^{\circ} \mathrm{C}$, fueron pelados y cortados longitudinalmente por la mitad, se eliminaron las semillas y las puntas, y luego se cortaron en rodajas, en la dirección transversal (1,5-2 cm de grosor) o se cortaron en 4 partes. Las piezas cortadas se enjuagaron, drenaron y embalaron en contenedores de tereftalato de polietileno (TPE) o en bandejas de espuma de poliestireno envueltas en película de cloruro de polivinilo (CPV) y almacenadas a 4 u $8^{\circ} \mathrm{C}$. Durante el almacenamiento, se evaluaron: sólidos solubles, acidez titulable, vitamina C, color (luminosidad, ángulo hue y chroma), textura, pérdida de peso y apariencia. De acuerdo con las evaluaciones físico-químicas, los productos mantuvieron la calidad adecuada para el consumo y la comercialización, hasta por nueve días, presentando los productos almacenados a $4{ }^{\circ} \mathrm{C}$, mejor mantenimiento de la textura, color, menor pérdida de peso y mayores niveles de vitamina $\mathrm{C}$ que los almacenados a $8^{\circ} \mathrm{C}$. El envase de PET minimizó la pérdida de peso y las rodajas partidas en la dirección transversal presentaron menos daño en los tejidos, además mantuvieron la calidad y características similares a las de la fruta fresca.

Palabras clave: Almacenamiento, calidad, papaya "Formosa", poscosecha, textura.

\section{Introduction}

Originally from America, the papaya (Carica papaya L.) is grown in more than 40 countries, with Brazil as the main world producer. The national papaya production in Brazil focuses on 'Hawaii' and 'Formosa' types, with 'Formosa' mainly aimed at the domestic market (Rocha et al., 2005). The pleasant taste, good sugar content, low acidity, balance of nutrients and presence of vitamin C makes papaya a fruit that is greatly appreciated by consumers. It is known for its nutritional and beneficial properties to human health, and as an attraction for fresh markets and industry, and has achieved one of the largest growths in consumption in recent years (Martins, 2005).

The papaya is one of the most cultivated fruit trees and shows high consumption in tropical and subtropical regions of the world, with annual worldwide production of approximately 12.4 million tons (F.A.O., 2013). Brazil is the second largest producer of papaya, mainly in the states of Bahia and Espirito Santo, responsible for about $90 \%$ of national production, showed an export volume of 37.9 tons in 2016, is among the main exporting countries and exports its production mainly to the European market (Carvalho et al., 2017).

Although papaya is usually consumed fresh, its use is limited by the inconvenience of complicated peeling and the need for an adequate container for the fruit before it is consumed. The rate of consumption could be increased if properly packaged pieces were available for consumers in market, allowing it to be eaten more frequently and facilitating its use in various food services (Durigan \& Durigan, 2014).

Fresh produce has an increasingly important place in the human food supply as the nutritional properties they contain promote health (Cardamone et al., 2015). Minimally processed foods are a growing market trend that are practical for the consumer, provide agility in meal preparation and allow products to 
maintain the nutritional and sensory qualities of the fresh produce while giving an extended shelf-life (Nascimento et al, 2014).

There are some issues related to logistics involved in production and preservation of these products, essentially in the distribution channel and marketing, in which the maintenance of the cool chain is essential (Santos \& Oliveira, 2012), therefore, the use of unconventional tools to preserve and extend the quality of minimally processed fruits and vegetables seem to be the future trend for improved products (Corbo et al., 2015).

The operations carried out in the minimally processed fruit and vegetable products (peeling, seed withdrawal, cutting, etc.) can cause significant mechanical damage to plant products, causing increase the respiratory activity and ethylene production with a consequent increase in biochemical effects, including enzymatic discoloration and loss of flavor, firmness and nutritional qualities (Del Caro et al., 2004). The peeling and cutting process promotes the release of enzymes, causing darkening of the fruit surface and negatively affecting the appearance of the product ( $\mathrm{Ra}$ gaert et al., 2011).

According to Zubiolo et al. (2012) papaya is one of the best fruits in the world, both for its nutritional value, as for its medicinal power. So, due to economic importance related of consumption and for increasing research on minimally processed papaya, this study has been developed. The present study was conducted in the conditions of the city of Muzambinho in the southern state of Minas Gerais, Brazil, to evaluate physicochemical aspects related to the influence of packaging type, cut type and storage time in two storage temperatures (4 ${ }^{\circ} \mathrm{C}$ and $8^{\circ} \mathrm{C}$ ) on the minimally processed papaya cv. 'Formosa'.

\section{Material and Methods}

The 'Formosa' papaya was purchased at a local market in Muzambinho-MG, Brazil, at the commercial maturation stage (with up to $25 \%$ of the surface yellow), without detectable physiological defects and infections. Fruits were matured until they reached level 3 (50\% to $75 \%$ of yellow skin) as indicated by Lima et al. (2005). Then, fruits were transported to the industry sector of the Federal Institute of the South of Minas Gerais - Muzambinho Campus, where they went through a process of selection, washing, sanitization with sodium hypochlorite (200 $\mathrm{mg}^{-1}$ ) and storage for $12 \mathrm{~h}$ at $10^{\circ} \mathrm{C}$. After cold storage, the fruits were moved to a cold room $\left(12^{\circ} \mathrm{C}\right)$ where they were peeled, cut longitudinally in half, the seeds and tips were removed, and then either cut into slices in the transverse direction about $1.5-2-\mathrm{cm}$ thick (cut 1 ) or cut into 4 parts (cut 2). They were then rinsed in sodium hypochlorite $\left(20 \mathrm{mg} \cdot \mathrm{L}^{-1}\right)$, drained and packed either in polyethylene terephthalate (PET) containers or on Styrofoam trays wrapped in polyvinyl chloride (PVC) film and stored at 4 or $8^{\circ} \mathrm{C}$. Sources of contamination during processing were minimized by sanitizing utensils with a sodium hypochlorite solution (200 mL. $\mathrm{L}^{-1}$ ); operators wore gloves, aprons, caps and masks.

The following chemical characteristics of the fruit were evaluated during storage: soluble solids content - obtained using a digital refractometer (Atago PR 101) with results expressed in ${ }^{\circ}$ Brix (A.O.A.C., 2012); titratable acidity - $10 \mathrm{~g}$ samples of homogenized pulp which were titrated with a standard $0.1 \mathrm{~N}$ sodium hydroxide solution until the samples reached $\mathrm{pH} 8.1$, with results expressed as $\mathrm{g}$ citric acid.100 $\mathrm{g}^{-1}$ (A.O.A.C., 2012); and vitamin $\mathrm{C}$ content - quantified in $10 \mathrm{~g}$ of pulp homogenate that was diluted in $50 \mathrm{~mL}$ of $5 \%$ oxalic acid and then titrated with Tillman reagent 
( $0.1 \%$ sodium 2.6 -dichlorophenolindophenol), with results expressed as $\mathrm{mg}$ ascorbic acid.100 $\mathrm{g}^{-1}$ of pulp (A.O.A.C., 2012).

The following physical characteristics of the fruit were evaluated during storage: color determined using a chroma meter that expressed the results according to the system proposed by Commission Internationale de L'eclaraige (CIE) in the L*a*b* color space, reported as the variables lightness $\left(L^{*}\right)$, color (hue angle) and chromaticity (chroma) (Minolta Corp., 1994); appearance - recorded and evaluated using a 5-point scale according Souza (2005) where: 1 = great ("fresh" appearance and natural color), 2 = good, 3 = regular (signs of wilting and/or drying and early softening), $4=$ poor and $5=$ very poor (wilting and/or dryness, darkening and softening), in which the minimally processed product was considered still suitable for sale if scoring up to 3 on the scale; texture - obtained using a penetrometer with an 8-mm tip, with three pieces of fruit in each package tested and results expressed in Newtons; and weight loss - measured using an analytical balance with $1200-\mathrm{g}$ capacity and $0.1-\mathrm{g}$ accuracy, calculated as the difference between the final weight and the initial weight of the package and expressed in percentage (\%) of weight loss.

During storage, three replicates of $25 \mathrm{~g}$ of sample were transferred to $225 \mathrm{~mL} 0.1 \%$ peptone water, and from this, dilutions up to 10-4 were prepared. Afterwards, microbiological analyses were performed using the method described by Silva et al. (2010). The presence of Staphylococcus was evaluated by surface-scattering in Baird-Parker agar medium and incubated at $35^{\circ} \mathrm{C}$ for $48 \mathrm{~h}$. The presence of Salmonella $s p$. was determined with pre-enrichment in lactose broth, with incubation at $35^{\circ} \mathrm{C}$ for $24 \mathrm{~h}$, followed by selective enrichment in tetrathionate broth and Rappaport's broth at 35 and $42{ }^{\circ} \mathrm{C}$, respectively, for $24 \mathrm{~h}$. For total and fecal coliforms, the most probable number (MPN.g-1) technique was adopted, in which aliquots were inoculated in Lauryl Sulphate Tryptose broth (LST) with an inverted Duhran tube (presumptive test). Tubes were incubated at $35^{\circ} \mathrm{C}$ for $24-48 \mathrm{~h}$. Confirmatory tests for thermotolerant coliforms in Escherichia coli broth (EC) at $45.5^{\circ} \mathrm{C}$ for $24 \mathrm{~h}$ were performed in the tubes with positive reading (turbidity and gas formation).

Data were analyzed as a split plot design in a factorial scheme, the plots corresponding to package type (PET containers or Styrofoam trays wrapped in PVC film) X cut type (Cut 1 or Cut 2) and the sub-plots storage times (3, 6, 8 and 12 days), in completely randomized design, with three replicates, each experimental unit was a package containing $300-400 \mathrm{~g}$ of product. Data was evaluated at two storage temperatures $\left(4^{\circ} \mathrm{C}\right.$ and $8^{\circ} \mathrm{C}$ ) and was submitted for variance analysis, the means of the analyzed parameters were submitted to the Tukey test with a $5 \%$ level of error probability. Statistical analysis was performed using Sisvar software (Ferreira, 2011).

\section{Results and Discussion}

Freshly processed 'Formosa' papayas stored at $4{ }^{\circ} \mathrm{C}$ and $8{ }^{\circ} \mathrm{C}$ did not show significant variation in the soluble solids contents in relation to the storage time and package type, all results were around $11{ }^{\circ}$ Brix, as can be seen in Table 1 . The only variation was in the storage at $8^{\circ} \mathrm{C}$ where there was a slight decrease for cut type 2, which was similar to that observed by Argañosa et al. (2008) for minimally processed papaya cut into cylinders. In general, the observed values are in agreement with those presented by Oliveira Júnior et al. (2007) and Souza et al. (2005). 
Table 1. Means of variables soluble solids ('Brix), titratable acidity (g citric acid.100g ${ }^{-1}$ ) and vitamin C (mg ascorbic acid. $100 \mathrm{~g}^{-1}$ ) of minimally processed 'Formosa' papaya products stored at $4^{\circ} \mathrm{C}$ and $8^{\circ} \mathrm{C}$.

\begin{tabular}{|c|c|c|c|c|c|c|}
\hline & \multicolumn{2}{|c|}{ Soluble Solids } & \multicolumn{2}{|c|}{ Titratable Acidity } & \multicolumn{2}{|c|}{ Vitamin C } \\
\hline & $4^{\circ} \mathrm{C}$ & $8^{\circ} \mathrm{C}$ & $4^{\circ} \mathrm{C}$ & $8^{\circ} \mathrm{C}$ & $4^{\circ} \mathrm{C}$ & $8^{\circ} \mathrm{C}$ \\
\hline \multicolumn{7}{|c|}{ Package } \\
\hline PET & $10.80^{a}$ & $11.13^{a}$ & $0,06^{a}$ & $0,08^{a}$ & $57.99^{a}$ & $50.19^{a}$ \\
\hline Styrofoam & $10.98^{a}$ & $11.33^{a}$ & $0.06^{a}$ & $0.08^{a}$ & $57.92^{a}$ & $51.38^{a}$ \\
\hline \multicolumn{7}{|c|}{ Cut } \\
\hline Cut 1 & $10.87^{a}$ & $11.56^{a}$ & $0.06^{a}$ & $0.08^{a}$ & $58.41^{a}$ & $52.47^{a}$ \\
\hline Cut 2 & $10.91^{a}$ & $10.90^{b}$ & $0.06 a$ & $0.08^{a}$ & $57.50^{a}$ & $49.10^{b}$ \\
\hline \multicolumn{7}{|c|}{ Time (Days) } \\
\hline 3 & $11.06^{a}$ & $11.23^{a}$ & $0.06^{a}$ & $0.07^{b}$ & $61.27^{a}$ & $53.04^{a}$ \\
\hline 6 & $10.67^{a}$ & $11.14^{a}$ & $0.06^{a}$ & $0.07^{b}$ & $53.85^{c}$ & $51.34^{a}$ \\
\hline 9 & $10.73^{a}$ & $11.20^{a}$ & $0.07^{a}$ & $0.07^{b}$ & $59.46 a b$ & $48.73^{a}$ \\
\hline 12 & $11.10^{a}$ & $11.35^{a}$ & $0.06^{a}$ & $0.09^{a}$ & $57.24 b c$ & $50.04^{a}$ \\
\hline \multicolumn{7}{|c|}{ F Test } \\
\hline Package X Cut & 0.01 NS & 0.12 NS & 0.51 NS & $0.43^{N S}$ & $1.86^{N S}$ & $0.39 \mathrm{NS}$ \\
\hline Package $X$ Time & 1.95 NS & 0.99 NS & $0.13^{N S}$ & $0.77^{N S}$ & 0.95 NS & $1.23^{N S}$ \\
\hline Cut $X$ Time & $0.26^{N S}$ & $0.14^{N S}$ & $1.34^{N S}$ & $0.09 \mathrm{NS}$ & $0.70 \mathrm{NS}$ & 0.09 NS \\
\hline Pack. X Cut X Time & $0.48^{N S}$ & 0.94 NS & 1.24 NS & $1.18^{N S}$ & 0.95 NS & $0.00 \mathrm{NS}$ \\
\hline
\end{tabular}

Means followed by the same lowercase letter in the column, for each variable and temperature, do not differ significantly $(* \mathrm{P}<0.05)$.

No significant differences were observed in titratable acidity contents, for package or cut type (Table 1 ). In the $8{ }^{\circ} \mathrm{C}$ storage there was an increase in titratable acidity during the storage period, caused by the maturation process. During storage time, there is loss of firmness which increases organic acids as a product of the pectinamethylesterase activity (Costa \& Balbino, 2002).

Regarding ascorbic acid values (Vitamin C), no significant differences were observed for package type, however, there was a decrease in content for cut type 2 stored at $8^{\circ} \mathrm{C}$ (Table 1 ). In general, the ascorbic acid contents in fruit stored at $4{ }^{\circ} \mathrm{C}$ (53.85 to $61.27 \mathrm{mg}$ of ascorbic acid. $100 \mathrm{~g}^{-1}$ of pulp) were higher than those stored at $8{ }^{\circ} \mathrm{C}$ (48.73 to $53.04 \mathrm{mg}$ of ascorbic acid. $100 \mathrm{~g}^{-1}$ of pulp), but are still lower than the $76.7 \mathrm{mg}$ of ascorbic acid. $100 \mathrm{~g}^{-1}$ of pulp found by Souza et al. (2005).

The color variables (lightness, hue angle and chroma) were not influenced by the storage period (Table 2), however package and cut type did influence color. Cut type 2 showed a decrease in lightness, probably due to the greater processing leading to the decompartmentalisation of the enzymes and substrates, causing browning reactions. Such behavior is similar to that observed by Argañosa et al. (2008) where the cylinder type cut showed greater decreases in luminosity. 
Table 2. Means of variables Lightness ( $\left.L^{*}\right)$, color (Hue angle), chromaticity (Chroma) of minimally processed 'Formosa' papaya products stored at $4^{\circ} \mathrm{C}$ and $8^{\circ} \mathrm{C}$.

\begin{tabular}{|c|c|c|c|c|c|c|}
\hline & \multicolumn{2}{|c|}{ Lightness } & \multicolumn{2}{|c|}{ Color } & \multicolumn{2}{|c|}{ Chromaticity } \\
\hline & $4^{\circ} \mathrm{C}$ & $8^{\circ} \mathrm{C}$ & $4^{\circ} \mathrm{C}$ & $8^{\circ} \mathrm{C}$ & $4^{\circ} \mathrm{C}$ & $8^{\circ} \mathrm{C}$ \\
\hline \multicolumn{7}{|c|}{ Package } \\
\hline PET & $51.31^{b}$ & $51.16^{a}$ & $56.36^{b}$ & $55.13^{a}$ & $42.21^{a}$ & 42.65 \\
\hline Styrofoam & $54.79^{a}$ & $51.16^{a}$ & $57.56^{a}$ & $52.80^{b}$ & $43.07^{a}$ & $43.95^{\circ}$ \\
\hline \multicolumn{7}{|c|}{ Cut } \\
\hline Cut 1 & $53.73^{a}$ & $53.09^{a}$ & $57.45^{a}$ & $54.55^{a}$ & $42.80^{a}$ & $44.13^{\circ}$ \\
\hline Cut 2 & $52.37^{b}$ & $50.70^{b}$ & $56.46^{b}$ & $53.38^{a}$ & $42.48^{a}$ & $42.47^{\circ}$ \\
\hline \multicolumn{7}{|l|}{ Time (Days) } \\
\hline 3 & $53.38^{a}$ & $52.33^{a}$ & $56.95^{a}$ & $54.93^{a}$ & $42.91^{a}$ & $44.05^{\circ}$ \\
\hline 6 & $52.72^{a}$ & $52.16^{a}$ & $55.99^{a}$ & $53.89^{a}$ & $43.42^{a}$ & $43.83^{\circ}$ \\
\hline 9 & $53.47^{a}$ & $51.33^{a}$ & $57.93^{a}$ & $54.28^{a}$ & $42.39^{a}$ & $42.14^{\circ}$ \\
\hline 12 & $52.63^{a}$ & $51.77^{a}$ & $56.96^{a}$ & $52.75^{a}$ & $41.83^{a}$ & $43.17^{a}$ \\
\hline \multicolumn{7}{|c|}{ F Test } \\
\hline Package X Cut & $0.23^{N S}$ & 0.59 NS & 0.02 NS & $15.18^{*}$ & $0.44^{N S}$ & 0.43 Ns \\
\hline Package $X$ Time & $0.11^{N S}$ & $0.76^{N S}$ & $0.70^{N S}$ & $1.16^{N S}$ & $1.52 \mathrm{NS}$ & $1.21 \mathrm{NS}$ \\
\hline Cut $X$ Time & $0.36^{N S}$ & $2.33 \mathrm{NS}$ & $0.54^{N S}$ & $2.91^{*}$ & $0.95^{N S}$ & $1.55 \mathrm{NS}$ \\
\hline Pack. X Cut X Time & 1.69 NS & $1.98^{N S}$ & $2.38^{*}$ & $12.16^{*}$ & $0.50 \mathrm{NS}$ & $0.37 \mathrm{NS}$ \\
\hline
\end{tabular}

Means followed by the same uppercase letter in the column, for each variable and temperature, do not differ significantly $(* P<0.05)$.

The package types influenced the color at both temperatures, and the cut type influenced it at storage at $4{ }^{\circ} \mathrm{C}$, but chromaticity was influenced only by the cut type in products at $8{ }^{\circ} \mathrm{C}$ (Table 2). In general, those stored at 4 ${ }^{\circ} \mathrm{C}$ showed higher averages, which were larger on Styrofoam trays wrapped in polyvinyl chloride (PVC), while in those stored at $8{ }^{\circ} \mathrm{C}$ the highest averages were observed in PET packaging. This could be due to greater weight loss observed in the $8{ }^{\circ} \mathrm{C}$ temperature that accentuated the red coloration in the pulp, while at 4 ${ }^{\circ} \mathrm{C}$ there was better maintenance of the bright orange color of the product and less weight loss. At the $8^{\circ} \mathrm{C}$ there was decrease in the chromaticity for cut type 2 . In general, such behavior was also observed by Argañosa et al. (2008), in which minimally processed papaya cut into cubes or rectangular blocks retained their natural yellow/red color for 10 days of storage, whereas it decreased in the cylinder cut fruit during the storage period.

Texture softening was observed in fruit stored at $4{ }^{\circ} \mathrm{C}$ (Table 3 ), which was similar to that found by Cortez-Vega et al. (2013), whereas the packaging and cut type did not influence this variable. In storage at $8{ }^{\circ} \mathrm{C}$ there were no changes as a function of the storage time or cut type, but there was for the packaging type, where there was better texture maintained in the PET packaging. 
Table 3. Means of variables appearance, texture (Newtons) and weight loss (\%) of minimally processed 'Formosa' papaya products stored at $4{ }^{\circ} \mathrm{C}$ and $8{ }^{\circ} \mathrm{C}$.

\begin{tabular}{|c|c|c|c|c|c|c|}
\hline & \multicolumn{2}{|c|}{ Appearance } & \multicolumn{2}{|c|}{ Texture } & \multicolumn{2}{|c|}{ Weight Loss } \\
\hline & $4^{\circ} \mathrm{C}$ & $8^{\circ} \mathrm{C}$ & $4^{\circ} \mathrm{C}$ & $8^{\circ} \mathrm{C}$ & $4^{\circ} \mathrm{C}$ & $8^{\circ} \mathrm{C}$ \\
\hline \multicolumn{7}{|c|}{ Package } \\
\hline PET & $2.50^{a}$ & $2.62^{a}$ & $9.31^{a}$ & $7.23^{a}$ & $0.12^{b}$ & $0.24^{b}$ \\
\hline Styrofoam & $2.25^{a}$ & $2.54^{a}$ & $10.35^{a}$ & $5.51^{b}$ & $0.62^{a}$ & $0.59^{a}$ \\
\hline \multicolumn{7}{|c|}{ Cut } \\
\hline Cut 1 & $2.37^{a}$ & $2.46^{b}$ & $9.66^{a}$ & $6.78^{a}$ & $0.39^{a}$ & $0.43^{a}$ \\
\hline Cut 2 & $2.37^{a}$ & $2.70^{a}$ & $10.00^{a}$ & $5.96^{a}$ & $0.35^{a}$ & $0.40^{a}$ \\
\hline \multicolumn{7}{|c|}{ Time (Days) } \\
\hline 3 & $1.50^{c}$ & $2.08^{c}$ & $10.82^{a}$ & $6.04^{a}$ & $0.16^{d}$ & $0.21^{c}$ \\
\hline 6 & $2.08^{b}$ & $2.58^{b}$ & $9.88^{a b}$ & $6.94^{a}$ & $0.32^{c}$ & $0.42^{b}$ \\
\hline 9 & $2.50^{a}$ & $2.83^{b}$ & $10.69^{a}$ & $5.96^{a}$ & $0.44^{b}$ & $0.44^{b}$ \\
\hline 12 & $2.83^{a}$ & $3.42^{a}$ & $7.92^{b}$ & $6.53^{a}$ & $0.57^{a}$ & $0.59^{a}$ \\
\hline \multicolumn{7}{|c|}{ F Test } \\
\hline Package $X$ Cut & 1.33 NS & $0.00 \mathrm{NS}$ & $6.91 *$ & $0.02 \mathrm{NS}$ & $0.01 \mathrm{NS}$ & $2.07 \mathrm{NS}$ \\
\hline Package $X$ Time & $0.56^{N S}$ & $0.17^{N S}$ & $1.32 \mathrm{NS}$ & $0.58^{N S}$ & $18.49^{*}$ & $15.03 *$ \\
\hline Cut $X$ Time & $0.22 \mathrm{NS}$ & 1.50 NS & $0.75^{N S}$ & $0.08^{N S}$ & $5.20^{*}$ & $2.54^{N S}$ \\
\hline Pack. X Cut X Time & 0.22 NS & $0.33^{N S}$ & 2.80 NS & $0.38^{N S}$ & 2.27 NS & $4.61 *$ \\
\hline
\end{tabular}

Means followed by the same lowercase letter in the column, for each variable and temperature, do not differ significantly $(* P<0.05)$. Notes for appearance: $1=$ great; $2=$ good; $3=$ regular; $4=$ poor and $5=$ very poor.

The lower storage temperature $\left(4^{\circ} \mathrm{C}\right)$ minimized the softening of the fruit pieces, which is consistent with the results from Souza et al. (2005) that in minimally processed products of 'Formosa' papaya kept at $9{ }^{\circ} \mathrm{C}$, there was greater softening of the pulp, while the lower temperatures $\left(3^{\circ} \mathrm{C}\right.$ and $6^{\circ} \mathrm{C}$ ) minimized this softening. These changes can be attributed to changes in the structures and composition of the cell wall by the action of enzymes. The pectinamethylesterase plays a key role in the papaya ripening process, because it converts pectins with high methoxylation content into pectins with low content, which in turn can be hydrolyzed to pectates, softening their tissues during this process (Jiang et al., 2003).
Fresh weight loss seen during the storage period of fruit products is due to the increased exposure of tissues to the environment and structure disruption, facilitating water loss by the tissues, and reducing the quality and shelf life (Tatsumi et al., 1991). Table 3 shows that the losses in the products kept on Styrofoam trays wrapped in polyvinyl chloride (PVC) were always higher, which was attributed to the greater permeability of the packaging used. There were no significant differences for the cut type. This study showed there was a gradual increase in weight loss for both storage temperatures and storage time increased. 
The appearance of the minimally processed products of 'Formosa' papaya stored at $4{ }^{\circ} \mathrm{C}$ and $8{ }^{\circ} \mathrm{C}$ showed variations during storage. The products maintained an adequate appearance for commercialization, indicated by a result below 3, until the 12th day for storage at $4{ }^{\circ} \mathrm{C}$, and up to the ninth day for storage at 8 ${ }^{\circ} \mathrm{C}$ (Table 3; Figure 1). No significant effect of the packaging type and cut type was observed from storage at $4{ }^{\circ} \mathrm{C}$, but at $8^{\circ} \mathrm{C}$ cut type 1 showed better appearance after storage. In general, in both storage temperatures, the products showed adequate quality for consumption and marketing higher than the 7 days for products stored at $3^{\circ} \mathrm{C}, 6^{\circ} \mathrm{C}$ and 9 ${ }^{\circ} \mathrm{C}$ detected by Teixeira et al. (2001), as well as the 8 days obtained for papaya cv. 'Golden' cut into cubes and stored at $5{ }^{\circ} \mathrm{C}$ (Oliveira Júnior et al., 2007). For storage at $4{ }^{\circ} \mathrm{C}$, the shelf life of the products was higher than the 10 days found by Souza et al. (2005) for 'Formosa' papaya stored at $3^{\circ} \mathrm{C}, 6^{\circ} \mathrm{C}$ and $9^{\circ} \mathrm{C}$.

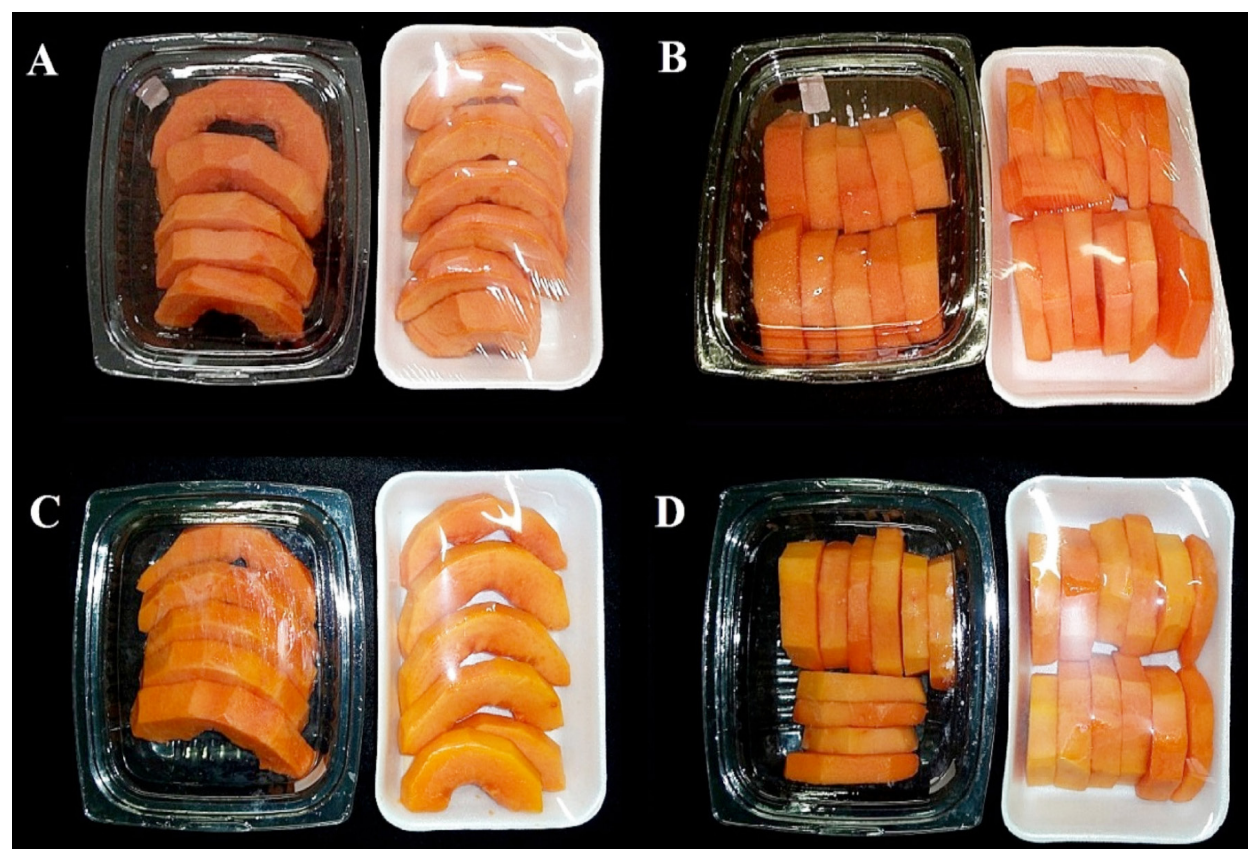

Figure 1. Appearance of the minimally processed products of papaya cv. 'Formosa'. A- Cut type 1 packed either in PET containers and Styrofoam trays wrapped in PVC film and stored at $4{ }^{\circ} \mathrm{C}$ for twelve days; B- Cut type 2 packed either in PET containers and Styrofoam trays wrapped in PVC film and stored at $4{ }^{\circ} \mathrm{C}$ for twelve days; C- Cut type 1 packed either in PET containers and Styrofoam trays wrapped in PVC film and stored at $8^{\circ} \mathrm{C}$ for nine days; D- Cut type 2 packed either in PET containers and Styrofoam trays wrapped in PVC film and stored at $8^{\circ} \mathrm{C}$ for nine days.

The control of the hygienic conditions during the products handling appeared to be sufficient, as the presence of Salmonella sp. and Staphylococcus was not detected during storage. The presence of thermotolerant coliforms $\left(45^{\circ} \mathrm{C}\right)$ did not reach $<0.3 \mathrm{MPN} . \mathrm{g}^{-1}$ during storage, which is lower than the $10^{2}$ MPN. $g^{-1}$ allowed by the Brazilian legislation
(RDC no. 12 of 01/02/2001) (Brasil, 2001).

\section{Conclusions}

Physicochemical results in this study showed that preparation processes used kept papaya at adequate quality for consumption and marketing $r$ up to 12 days at $4{ }^{\circ} \mathrm{C}$ and 9 days at $8{ }^{\circ} \mathrm{C}$. Products stored at $4{ }^{\circ} \mathrm{C}$ showed 
better maintenance of texture and coloring, lower weight loss and higher vitamin $\mathrm{C}$ content than those stored at $8^{\circ} \mathrm{C}$. PET packaging was more suitable for the minimization of weight loss, and cut type 1 (1.5-2-cm slices cut in the transverse direction) was more suitable as it caused less damage to the fruit tissues.

\section{Acknowledgements}

The authors thank to FAPEMIG - Research Support Foundation of the State of Minas Gerais, for the project financing (APQ-00926-09) and the scholarship grant awarded.

\section{Cited literature}

AOAC. (2012) Association of Official Analytical Chemistry. Official methods of analysis. (19th ed). Gaithersburg, MD: AOAC International. 3000p.

Argañosa, A. C. S. J.; Raposo, M. F. J.; Teixeira, P. C. M.; Morais, A. M. M. B. (2008) Effect of cuttype on quality of minimally processed papaya. J. Sci. Food Agric. 8 (12): 2050-2060. doi: http:// dx.doi.org/10.1002/jsfa.3309

Brasil. (2001) Ministério da Saúde. Agência Nacional de Vigilância Sanitária. Resolução no 12, de 2 de janeiro de 2001 - Definição de critérios e padrões microbiológicos para alimentos. Available in: <http://portal.anvisa.gov.br/documents/33880/2568070/RDC_12_2001.pdf/15f

fddf6-3767-4527-bfac-740a0400829b> Access in: 01 February 2017.

Carvalho, C.; Kist, B. B.; Santos, C. E.; Treichel, M.; Filter, C. F. (2017) Anuário Brasileiro de Fruticultura. Santa Cruz do Sul, RS: Editora Gazeta. 88p.

Corbo, M. R.; Campaniello, D.; Speranza, B.; Bevilacqua, A.; Sinigaglia, M. (2015) Non-Conventional Tools to Preserve and Prolong the Quality of Minimally-Processed Fruits and Vegetables. Coatings 5 (4): 931-961. doi: http://dx.doi. org/10.3390/coatings5040931

Costa, A. F. S.; Balbino, J. M. S. (2002) Características da fruta para exportação e normas de qualidade. In: Folegatti, M. I. S.; Matsuura, F. C. A. U. (Ed.) Mamão: Pós-colheita (12-18). Brasília, DF: Embrapa - Mandioca e Fruticultura. (Frutas do Brasil, publicação número 21).
Cardamone, C.; Aleo, A.; Mammina, C.; Oliveri, G.; Di Noto, A. M. (2015) Assessment of the microbiological quality of fresh produce on sale in Sicily, Italy: preliminary results. J. Bio. Res. 22 (1): 1-3. doi: http://dx.doi.org/10.1186/s40709-015-0026-3

Cortez-Vega, W. R.; Piotrowicz, I. B. B.; Prentice, C.; Borges, C. D. (2013) Conservação de mamão minimamente processado com uso de revestimento comestível à base de goma xantana. Semina: Ciências Agrárias 34 (4): 1753-1764. doi: http:// dx.doi.org/10.5433/1679-0359.2013v34n4p1753

Del Caro, A.; Piga, A.; Vacca, V.; Agabbio, M. (2004) Changes of flavonoids, vitamin $\mathrm{C}$ and antioxidant capacity in minimally processed citrus segments and juices during storage. Food Chemistry 84 (1): 99-105. https://doi.org/10.1016/S03088146(03)00180-8

Durigan, M. F.; Durigan, J. F. (2014) Tecnologia Póscolheita e Processamento de Mamão: Qualidade e Renda aos Produtores Roraimenses. Boa Vista, RR: EMBRAPA. 27p. (EMBRAPA publicação número 55).

F.A.O. Food and Agriculture Organization of the United Nations. (2013) FAO statistics agriculture database. Available in: <http://www.fao.org> Access in: 01 december 2017.

Ferreira, D. F. (2011) Sisvar: a computer statistical analysis system. Cien. Agrotec. 35 (6), 1.0391.042. doi: http://dx.doi.org/10.1590/S141370542011000600001

Jiang, C. M.; Wu, M. C.; Wu, C. L.; Chang, H. M. (2003) Pectinaesterase and polygalacturonase activities and textural properties of Rubbery papaya (Carica papaya Linn.). J. Food Sci. 68 (5): 1590-1594. doi: http://dx.doi.org/10.1111/j.1365-2621.2003. tb12296.x

Lima, A. S.; Ramos, A. L. D.; Marcellini, P. S.; Batista, R. A.; Faraoni, A. S. 2005. Adição de agentes antiescurecimento, antimicrobiano e utilização de diferentes filmes plásticos em mamão minimamente processado. Rev. Bras. Frutic. 27 (1): 149-152. doi: http://dx.doi.org/10.1590/S010029452005000100039

Martins, D. S. (2005) Papaya Brasil: mercado e inovações tecnológicas para o mamão. Vitória, ES: INCAPER. 666p.

Minolta Corp. (1994) Precise color communication: color control from feeling to instrumentation. Ramsey, ND: Minolta Corporation Instrument Systems Division. 49p. 
Nascimento, K. O.; Augusta, I. M.; Rodrigues, N. R.; Pires, T.; Batista, E.; Barbosa Júnior, J. L.; Barbosa, M. I. M. J. (2014) Alimentos minimamente processados: uma tendência de mercado. Acta Tecnológica 9 (1): 48-61.

Oliveira Júnior, L. F. G.; Carlos, L. A.; Cordeiro, C. A. M.; Coelho, E. M.; Araújo, T. M. R. (2007) Qualidade de mamão "Golden" minimamente processado armazenado em diferentes temperaturas. Scientia Agraria 8 (3) 219-224. doi: http:// dx.doi.org/10.5380/rsa.v8i3.9523

Ragaert, P.; Jacxsens, L.; Vandekinderen, I.; Baert, L.; Devlieghere, F. (2011) Microbiological and Safety Aspects of Fresh-Cut Fruits and Vegetables. In: Martín-Belloso, O.; Soliva-Fortuny, R. (Ed.). Advances in Fresh-Cut Fruits and Vegetables Processing (53-86). London: New York, CRC Press.

Rocha, R. H. C.; Nascimento, S. R. C. N.; Menezes, J. B.; Nunes, G. H. S.; Silva, E. O. (2005) Qualidade pós-colheita do mamão Formosa armazenado sob refrigeração. Rev. Bras. Frutic. 27 (3): 386-389. doi: http://dx.doi.org/10.1590/S010029452005000300012

Santos, J. S.; Oliveira, M. B. P. P. (2012) Revisão: Alimentos frescos minimamente processados embalados em atmosfera modificada. Braz. J. Food Technol. 15 (1): 1-14, 2012.

Silva, N.; Junqueira, V. C. A.; Silveira, N. F. A.; Taniwaki, M. H.; Santos, R. F. S.; Gomes, R. A. R. (2010) Manual de métodos de análise microbiológica de alimentos. (4 ed.) São Paulo, SP: Editora Varela. 624p.

Souza, B. S. (2005) Processamento mínimo de manga: ponto de colheita, embalagem, 1-MCP, aditivos e atmosfera controlada. Tese de doutorado em Agronomia. Universidade Estadual Paulista "Júlio de Mesquita Filho" - Faculdade de Ciências Agrárias e Veterinárias, Jaboticabal, São Paulo.

Souza, B. S.; Durigan, J. F.; Donadon, J. R.; Teixeira, G. H. A. (2005) Conservação de mamão 'Formosa' minimamente processado armazenado sob refrigeração. Rev. Bras. Frutic. 27 (2): 273-276. doi: http://dx.doi.org/10.1590/S010029452005000200021

Tatsumi, Y.; Watada, A. E.; Wergin, W. P. (1991) Scanning electron microscopy of carrot stick surface to determine cause of white translucent appereance. J. Food Sci. 56: 1357-1362. doi: http://dx.doi.org/10.1111/j.1365-2621

Teixeira, G. H. A.; Durigan, J. F.; Mattiuz, B.; Rossi Junior, O. D. (2001) Processamento mínimo de mamão 'Formosa'. Cien. Tecnol. Alim. 21 (1): 47-50. doi: http://dx.doi.org/10.1590/S010120612001000100011

Zubiolo, C.; Rodrigues, M. A. S.; Oliveira, M. C.; Aquino, L. C. L.; Nunes, M. L.; Castro, A. A. (2012) Estudo do desenvolvimento de bebida láctea funcional com adição de polpa de mamão e aveia. Scientia Plena 8 (3): 1-7. 